EPiC Series in Engineering
Volume 3, 2018, Pages 236-244
HIC 2018. 13th International
Conference on Hydroinformatics

\title{
Temporal Variation in Water Induced Soil Erosion by RUSLE Model using RS and GIS
}

\author{
A. Bhadra ${ }^{1 *}$, H. Lalramnghaki ${ }^{1 \dagger}$, L. G. Kiba ${ }^{1 \ddagger}$ and A. Bandyopadhyay ${ }^{1 \S}$ \\ ${ }^{1}$ North Eastern Regional Institute of Science and Technology, Nirjuli (Itanagar) and 791109, \\ Arunachal Pradesh, India \\ aditibhadra@yahoo.co.in, manghakihmar05@gmail.com, \\ leezasumi@gmail.com, arnabbandyo@yahoo.co.in
}

\begin{abstract}
Soil erosion by various agents is one of the major threats of land degradation throughout the world. Revised Universal Soil Loss Equation model integrated with remote sensing and GIS was employed to assess soil erosion in the Mago basin of Arunachal Pradesh, India for a period of ten years (2004-2013). The rainfall erosivity (R-factor) was calculated using ten years rainfall data. ASTER DEM of $30 \mathrm{~m}$ resolution was used to generate the LS-factor map. Soil map and soil samples were analyzed to generate soil erodibility (K) map. MODIS NDVI images were used to obtain C-factor maps. The average annual soil loss was estimated and spatial and temporal variations of annual soil erosion were analyzed. The largest portion of the snow or glacier free area was observed under slight erosion and the rest of the area under moderate to very severe erosion risk zones. The temporal variation in the area under slight soil erosion showed a decreasing trend. Increasing trends were observed over the years in areas under moderate to very severe soil erosion classes. The average soil loss by water for each year crossed permissible soil loss limit of $12 \mathrm{t} \mathrm{ha}^{-1}$ year $^{-1}$ except for the year 2006.
\end{abstract}

\section{Introduction}

Soil erosion is regarded as one of the major and most prevalent forms of land degradation. The continuous increase in erosion of the soil by various agents is a severe problem throughout the world. The mountain terrain in the state of Arunachal Pradesh covers an area of about $84,000 \mathrm{~km}^{2}$ with elevation ranging from 400 to $6000 \mathrm{~m}$ above the mean sea level. It was observed that about $42.5 \%$ of the total geographical area of the state requires adoption of appropriate conservation measures for

\footnotetext{
${ }^{*}$ Corresponding author and conceptualized the research work

${ }^{\dagger}$ Prepared the data and executed the work

${ }^{\ddagger}$ Created the first draft of this document

$\S$ Checked and finalized the manuscript
} 
erosion control [1] [2]. It was estimated by the application of Universal Soil Loss Equation (USLE) for Arunachal Pradesh that total amount of above 669.35 million tons of soil was eroded annually [3]. Revised Universal Soil Loss equation (RUSLE) is an empirical model, founded on the USLE [4]. It uses the same empirical principles as USLE, but is more diverse and includes numerous improvements in computation of various factors and databases [5]. The RUSLE model has been widely adopted for spatial prediction of soil loss and erosion risk [6]. As assessment of soil erosion through gauging stations is very limited in India due to lack of adequate funds, the RUSLE model is widely used for predicting erosion rates of un-instrumented catchments. In this study, the RUSLE model was adopted for water-induced soil erosion assessment in a high altitude Mago basin of Arunachal Pradesh, India.

The main objectives of the study were to generate spatial maps of soil erodibility factor (K), topography factor (LS), cover management factor (C) and conservation practice factor (P) for obtaining spatial variation in annual average soil loss across the Mago river basin of Arunachal Pradesh and to determine temporal variation in annual average soil loss over the period of time.

\section{Material and Methods}

\subsection{Description of Study Area}

Mago basin lies in the upstream of the Tawang river basin extending from $27^{\circ} 53^{\prime} 17.5^{\prime \prime} \mathrm{N}$ to $27^{\circ} 31^{\prime} 16.5^{\prime \prime} \mathrm{N}$ latitudes and $92^{\circ} 0^{\prime} 28.5^{\prime \prime} \mathrm{E}$ to $92^{\circ} 28^{\prime} 3.5^{\prime \prime} \mathrm{E}$ longitudes. The total area of the basin is 839 sq. km. The outlet of the Mago basin is situated at China Bridge which lies at $27^{\circ} 37^{\prime} 22^{\prime \prime} \mathrm{N}$ and $92^{\circ} 00^{\prime} 58^{\prime \prime} \mathrm{E}$. The elevation ranges from $2,355 \mathrm{~m}$ to $6,436 \mathrm{~m}$ and it is characterized by narrow undulating features. The annual rainfall in the basin averages $1,139 \mathrm{~mm}$. The Mago river which is a $3^{\text {rd }}$ order stream flows from west to east and divides the basin into northern region and southern region.

\subsection{Data Acquisition}

Daily rainfall data of 10 years period for the Mago basin were collected from Central Water Commission (CWC) office, Itanagar, Arunachal Pradesh. ASTER DEM with $30 \mathrm{~m}$ spatial resolution and MODIS/Terra Vegetation Indices 16-Day L3 Global $250 \mathrm{~m}$, MOD13Q1 dataset from 2004 to 2013 were used. Soil map and Land Use Land Cover (LULC) map for the study area were obtained from State Remote Sensing Application Centre (SRSAC), Department of Science and Technology, Govt. of Arunachal Pradesh. Soil samples were collected from different locations of the study area to obtain various soil properties. The LULC map and areal extent of different soil types in the study area are shown in Figure 1 and Table 1 respectively.

\subsection{Estimation of Water-Induced Soil Erosion}

The RUSLE equation is given as:

$\mathrm{A}=\mathrm{R} \times \mathrm{K} \times \mathrm{LS} \times \mathrm{C} \times \mathrm{P}$ 


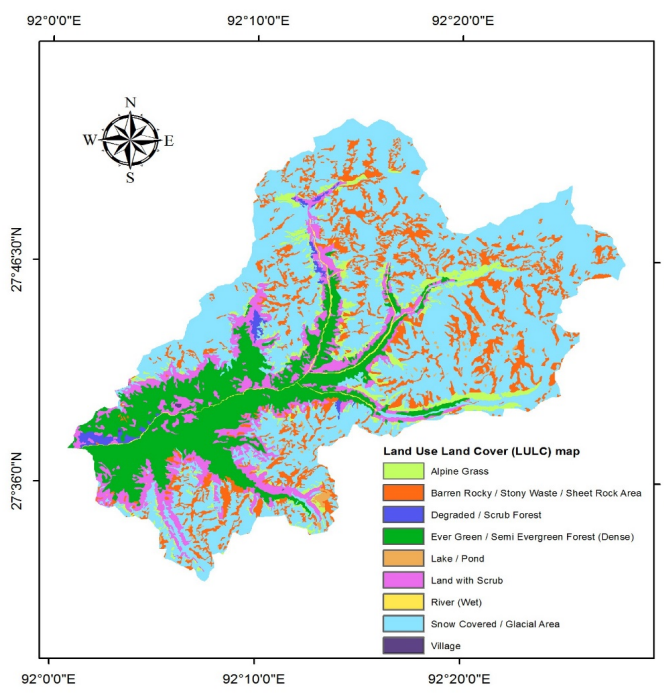

\begin{tabular}{|c|c|c|}
\hline Soil type & $\begin{array}{l}\text { Area } \\
\left(\mathrm{km}^{2}\right)\end{array}$ & $\begin{array}{c}\text { Percent area } \\
\text { coverage } \\
(\%)\end{array}$ \\
\hline Sandy & 256.24 & 30.55 \\
\hline Loamy & 195.16 & 23.26 \\
\hline Sandy loam & 4.92 & 0.59 \\
\hline Loamy sand & 36.88 & 4.40 \\
\hline $\begin{array}{l}\text { Rocky (Snow } \\
\text { cover) }\end{array}$ & 345.67 & 41.21 \\
\hline Total & 838.87 & 100 \\
\hline
\end{tabular}

Figure 1: LULC map of Mago basin

Where, $A=$ computed spatial average annual soil loss per unit of area $\left(\mathrm{t} \mathrm{ha}^{-1}\right.$ year $\left.{ }^{-1}\right)$ over a period selected for $R ; R=$ rainfall erosivity factor $\left(\mathrm{MJ} \mathrm{mm} \mathrm{ha} \mathrm{m}^{-1} \mathrm{~h}^{-1}\right.$ year-1); $K=$ soil erodibility factor $(\mathrm{t}$ ha $\mathrm{h}$ $\left.\mathrm{ha}^{-1} \mathrm{MJ}^{-1} \mathrm{~mm}^{-1}\right) ; L S=$ topographic/ slope length-steepness factor (dimensionless); $C=$ cover management factor (dimensionless); $P$ = support practice factor (dimensionless, ranging between 0 and 1).

Rainfall erosivity factor $(\mathrm{R})$ increases as the amount and intensity of rainfall increase.

$R=\sum_{i=1}^{12} 1.735 \times 10^{\left(1.5 \log 10\left(\frac{P_{i}{ }^{2}}{P}\right)-0.08188\right)}$

Where, $R=$ rainfall erosivity factor $\left(\mathrm{MJ} \mathrm{mm} \mathrm{ha}^{-1} \mathrm{~h}^{-1}\right.$ year $\left.^{-1}\right), P_{i}=$ monthly rainfall $(\mathrm{mm}), P=$ annual rainfall $(\mathrm{mm})$.

The $\mathrm{K}$ factor is related to the integrated effects of rainfall, runoff, and infiltration on soil loss, accounting for the influences of soil properties on soil loss during storm events on upland areas.

$K=2.8 \times 10^{-7} \times M^{1.14} \times(12-a)+4.3 \times 10^{-3} \times(b-2)+3.3 \times 10^{-3} \times(c-3)$

Where, $K=$ soil erodibility factor ( $\left.\mathrm{t} \mathrm{ha} \mathrm{h} \mathrm{ha-1} \mathrm{MJ}^{-1} \mathrm{~mm}^{-1}\right) ; M=$ Particle size parameter (\%silt + $\%$ very fine sand) (100 - \%clay); $a=$ percentage of organic matter content; $b=$ soil structure code; $c=$ permeability class/code.

The soil samples collected from different locations in the study area were analysed in the laboratory for determining the particle size parameter from soil texture classes, organic matter content and permeability. The hydrometer method was adopted for the textural analysis of the soil samples. Walkley-Black chromic acid wet oxidation method was used for determination of organic matter content. Raster calculator of Map Algebra in Spatial analyst tool of ArcGIS was used to derive LS map based on flow accumulation and slope steepness.

$L S=(\text { Flow accumulation } \times \text { cell size } / 22.1)^{0.4} \times($ sin slope $\left.\times 0.01745) / 0.09\right)^{1.4} \times 1.4$

Where, $L S=$ combined slope length and slope steepness factor; Flow accumulation $=$ the accumulated upslope contributing area for a given cell; cell size $=$ size of grid cell $(30 \mathrm{~m})$; sin slope $=$ slope degree value (sine). 
Due to the variety of land cover patterns with spatial and temporal variations, satellite remote sensing data sets were used for the assessment of C-factor [7]. The Normalized Difference Vegetation Index (NDVI) was used along with the following equation to calculate the $\mathrm{C}$ factor values using raster calculator of ArcGIS spatial analyst tool.

$$
C=\operatorname{Exp}\left[-\alpha \frac{N D V I}{\beta-N D V I}\right]
$$

Where, $\alpha$ and $\beta$ are unit less parameters that determine the shape of the curve relating to NDVI and the $C$-factor.

The temporal variation of mean $\mathrm{C}$ value was analysed by plotting a graph between annual mean $\mathrm{C}$ values and year. The Land Use/Land Cover map of the study area was overlaid on the averaged $\mathrm{C}$ factor map of 2013 to validate the ' $\mathrm{C}$ ' values for different LULC classes in the study area. The C factor values of the year 2013 based on MODIS image of the study area were extracted and these $\mathrm{C}$ values as obtained for each LULC classes were compared with corresponding $\mathrm{C}$ values from published literatures (Table 2).

The P-factor value was used for understanding the conservation practices being taken up in the study area. $P$ value of 1 was assigned to pixels where no support/conservation practices were adopted [1] [8] [9] and $P$ value of 0 was assigned to snow covered pixels [10].

\subsection{Spatial Distribution of Annual Average Soil Loss}

The spatial distribution of average annual soil loss in the basin was determined for 10 years period (2004-2013) for $30 \mathrm{~m} \times 30 \mathrm{~m}$ size grids/cells. The spatially distributed raster-based maps of the resulted soil erosion estimates were classified into six priority classes, namely slight, moderate, high, very high, severe, and very severe based on the scheme introduced for Indian conditions [11] [12].

\begin{tabular}{lcccc}
\hline Land Use/ & C derived from NDVI & & \multicolumn{2}{c}{ C from published literature } \\
\cline { 2 - 2 } \cline { 5 - 6 } Land Cover classes & Mean & & C value & Source \\
\cline { 1 - 2 } Snow covered glacial/ Glacial area & 0.00 & & 0.00 & {$[10]$} \\
Barren rocky/ sheet rock area & 0.77 & & 0.78 & {$[13]$} \\
Alpine grass & 0.44 & & 0.45 & {$[14]$} \\
Land with scrub & 0.22 & & 0.10 & {$[14]$} \\
Degraded/ scrub forest & 0.14 & & 0.10 & {$[6]$} \\
Evergreen/ semi-evergreen forest & 0.07 & & 0.05 & {$[4]$} \\
Village & 0.11 & & 0.25 & {$[14]$} \\
Lake/ pond & 0.00 & & 0.00 & {$[6]$} \\
River (wet) & 0.00 & & 0.00 & {$[6]$} \\
\hline
\end{tabular}

Table 2: C-factor values for different LULC classes of Mago basin

\subsection{Temporal Variation in Annual Soil Loss}

The temporal variation in annual soil loss can be determined by comparing the annual average soil loss for each year over the study area. In the present study, the rate of soil erosion for a period of ten years (2004-2013) was assessed. Under this study, the variability of soil loss over time was mainly contributed by the variations in rainfall erosivity and crop management factors. The temporal variations in area under different soil erosion classes were estimated and the trend of area coverage under each soil erosion classes over the years were also determined. 


\section{Results and Discussion}

The R-factor values were found to be in the range of $1,334.64$ to $6,376.30 \mathrm{MJ} \mathrm{mm} \mathrm{ha}^{-1} \mathrm{~h}^{-1}$ year $^{-1}$ over the period 2004 to 2013 . The average R-factor value was observed to be $3,712.48 \mathrm{MJ} \mathrm{mm} \mathrm{ha}^{-1} \mathrm{~h}^{-1}$ year $^{-1}$. The particle size parameter $(\mathrm{M})$, percentage of organic matter (a), structure code (b), and permeability code (c) were computed and K map was prepared (Figure 2). The K-factor ranged from 0.004 to 0.093 . The LS factor ranged from 0 (low) to 67.40 (high) in the basin with mean and standard deviation of 0.29 and 0.64, respectively (Figure 3). Using the NDVI images, C-factor maps were generated for each year and ten years average mean $\mathrm{C}$ factor map was generated (Figure 4). A slight decreasing trend over the years was observed. As there is no agricultural/crop land prevailing in the study area, P-factor of 1 was assigned for all the land use land cover classes except for the snow covered area where it was assigned as 0 (Figure 5). The average annual soil loss, $\mathrm{A}\left(\mathrm{t} \mathrm{ha}^{-1} \mathrm{year}^{-1}\right)$ was estimated after the parameters of RUSLE had been computed. The calculation was done by Raster Calculator in ArcMap spatial analyst tool. The area under snow cover/glacier gave zero soil erosion as the $\mathrm{C}$ and $\mathrm{P}$ factors of the area under this LULC class were 0. For spatial and temporal soil loss analysis, Mago basin area (excluding snow covered/ glacial area) of 401.24 sq. $\mathrm{km}$ was considered.

\subsection{Spatial distribution of annual average soil loss}

The spatial distribution of annual average soil loss map is shown in Figure. From the ten years average annual soil loss map, dark orange region indicates the areas with slight soil loss $\left(<5 \mathrm{t} \mathrm{ha}^{-1}\right.$ year $\left.^{-1}\right)$ and dark blue region indicates very severe erosion risk zones $\left(>80 \mathrm{t} \mathrm{ha}^{-1}\right.$ year $\left.{ }^{-1}\right)$. The white portion of the map indicates no soil erosion zone, which is under snow cover or glacier. The largest percentage $(56.65 \%)$ of the snow/glacier free area (401.24 sq. km.) of Mago basin falls under slight erosion and the smallest percentage (4.7\%) under very severe erosion. Table 3 shows the area under different classes of soil erosion in the Mago basin.

\subsection{Temporal variation of average soil loss}

The temporal variation in annual soil loss was determined by comparing the annual soil loss for each year over the study area by observing and computing the variations in the rainfall erosivity (R) and cover management (C) factors over the study period. In the present study, the rate of soil erosion for a period of ten years (2004-2013) was assessed. The temporal trends in annual soil loss under each soil erosion class were also assessed. Figure shows the temporal variation of annual soil loss under each soil erosion class, i.e., slight soil erosion $\left(5 \mathrm{t} \mathrm{ha}^{-1}\right.$ year $\left.^{-1}\right)$, moderate soil erosion $\left(5-10 \mathrm{t} \mathrm{ha}^{-1}\right.$ year-1), high soil erosion (10-20 $\mathrm{tha}^{-1}$ year-1), very high soil erosion $\left(20-40 \mathrm{t} \mathrm{ha}^{-1}\right.$ year $\left.{ }^{-1}\right)$, severe soil erosion (40-80 $\mathrm{t} \mathrm{ha}^{-1}$ year $\left.{ }^{-1}\right)$ and very severe soil erosion $\left(>80 \mathrm{t} \mathrm{ha}^{-1}\right.$ year $\left.^{-1}\right)$. The temporal variation in the area under slight soil erosion showed a decreasing trend. Increasing trends were observed over the years in areas under moderate to very severe soil erosion classes. That indicated the requirement of adaptation to conservation practices in the study area. The temporal variation of the average soil loss showed an increasing trend as shown in Figure 8. The average soil loss by water for each year crossed permissible soil loss limit of $12 \mathrm{t} \mathrm{ha}^{-1}$ year $^{-1}$ except for the year 2006 when the annual rainfall erosivity factor $(R)$ was minimum. 


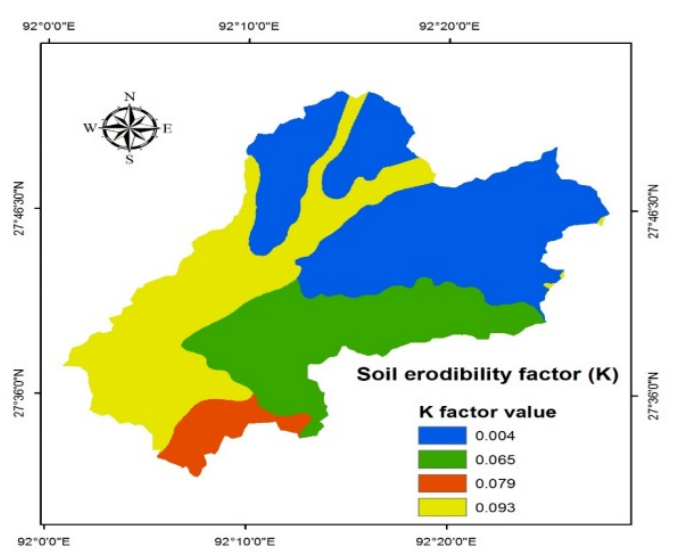

Figure 2: Soil erodibility factor, K map

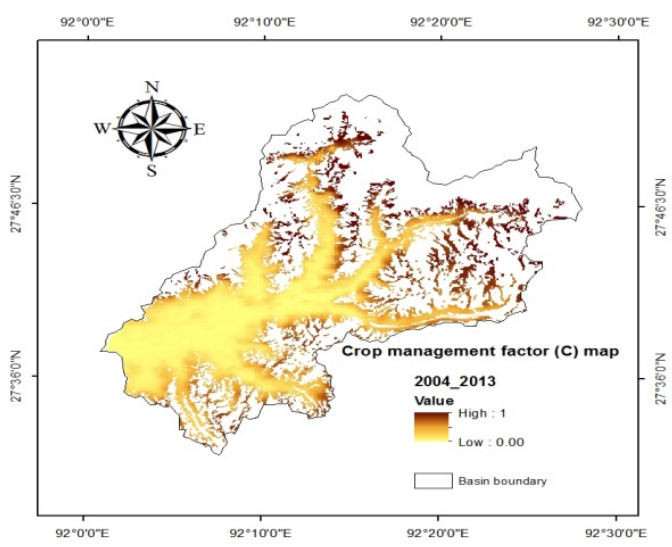

Figure 4: 10 years average mean $\mathrm{C}$ factor map

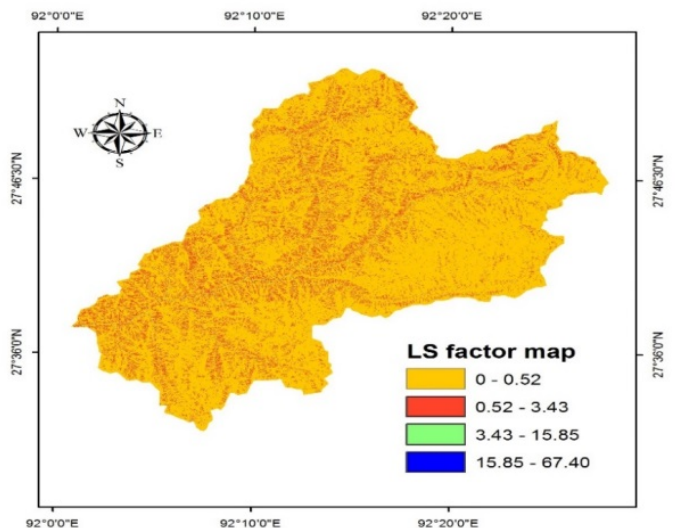

Figure 3: LS factor map

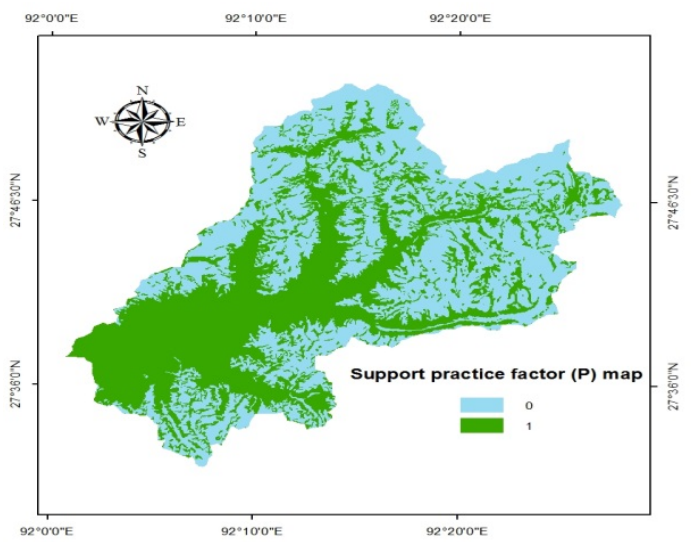

Figure 5: Support practice factor, P map

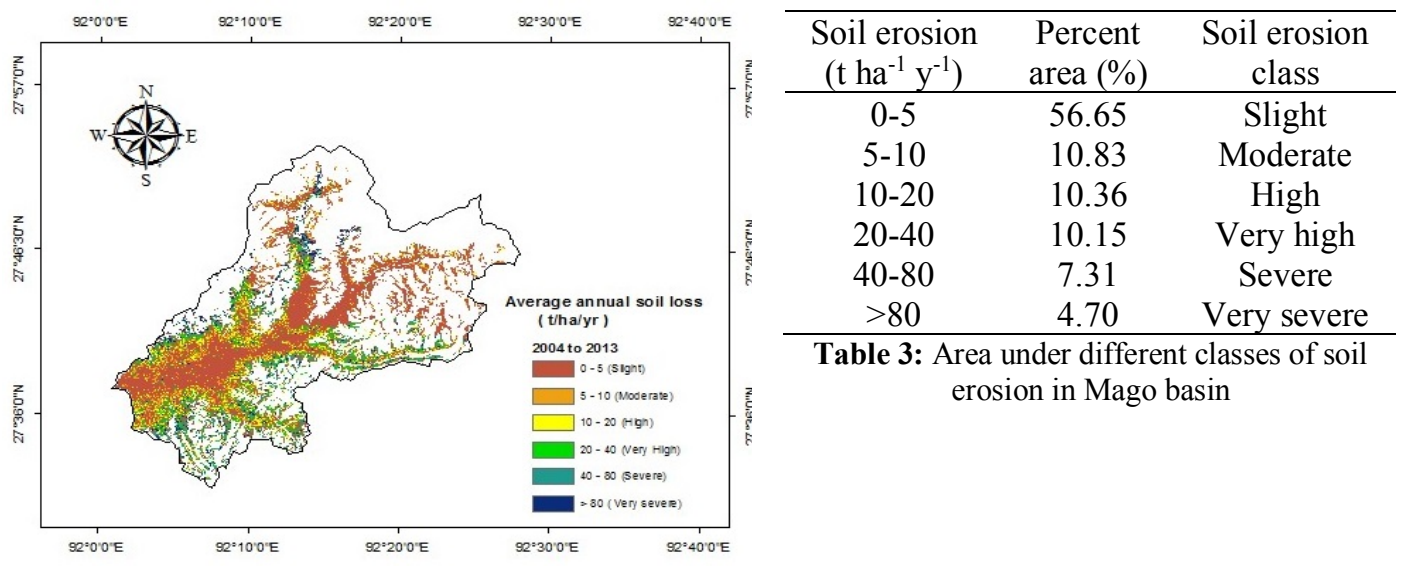

Figure 6: Ten years average annual soil loss 


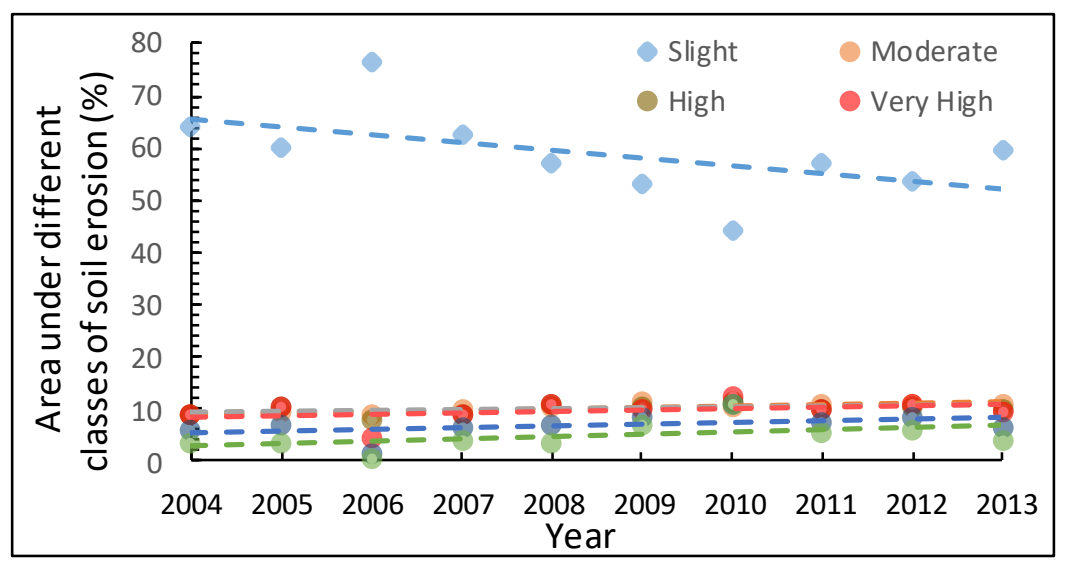

Figure 7: Temporal variation of area under different classes of soil erosion

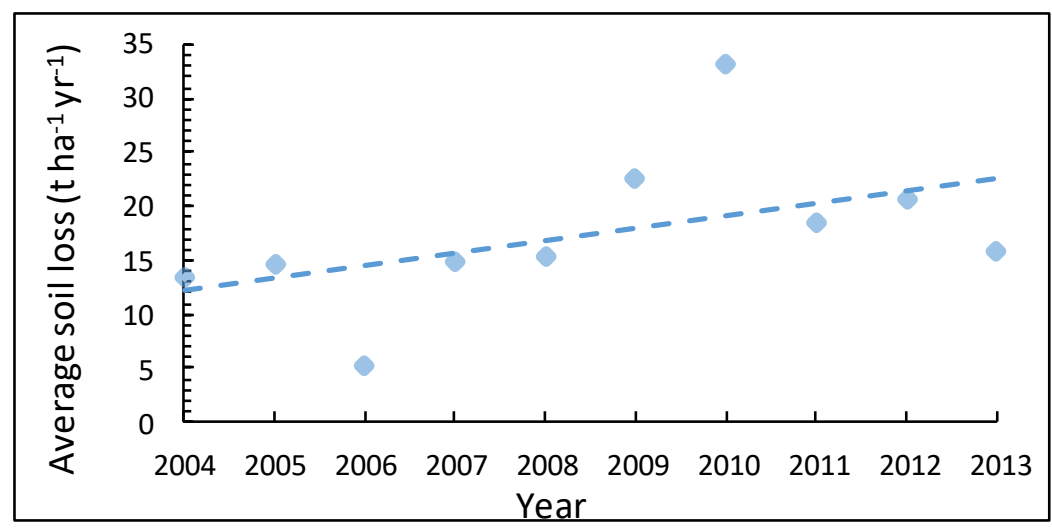

Figure 8: Temporal variation of the average soil loss

\section{Conclusions}

This study showed a very important application of geo-informatics for natural resources management in un-instrumented basins. The average annual soil loss map was prepared and it was found that $56.65,10.83,10.36,10.15,7.31,4.70$ percent areas of the snow/glacier free area of the Mago basin fell under slight, moderate, high, very high, severe, and very severe erosion classes, respectively. Maximum portion of snow/glacier free area of the study basin experienced slight erosion and the rest of the area fell under moderate to very severe erosion risk zones, which matched with the findings of Dabral et al. [1], where maximum portion of the Dikrong basin in Arunachal Pradesh was found to fall under slight and moderate erosion class. The temporal variation in area under slight soil erosion showed a decreasing trend. The areas under moderate to very severe erosion were found to have increasing trend. Hence, to minimize erosion risk in the study basin, adoption of standardized conservation measures considering local topographic variation is suggested. 


\section{References}

[1] P. P. Dabral, N. Baithuri and A. Pandey, "Soil Erosion Assessment in a Hily Catchment of North Eastern India Using USLE, GIS and Remote Sensing," Water Resources Management, vol. 22, pp. 1783-1798, 2008.

[2] V. N. Sharda, D. Mandal and P. R. Ojasvi, "Identification of soil erosion risk areas for conservation planning in different states of India," Journal of Environmental Biology, vol. 34, pp. 219-226, 2012.

[3] S. Singh, "A Resource Atlas of Arunachal Pradesh," Government of Arunachal Pradesh, Itanagar, 1999.

[4] W. H. Wischmeier and D. D. Smith, "Predicting Rainfall Erosion Losses - A Guide to Conservation Planning. Agriculture Handbook No. 537," US Department of Agriculture, Washington, DC, 1978.

[5] K. G. Renard, G. R. Foster, G. A. Weesies, D. K. McCool and D. C. Yoder, "Predicting Soil Erosion by Water: A Guide to Conservation Planning with the Revised Universal Soil Loss Equation (RUSLE). Agriculture Handbook No. 703," US Department of Agriculture, Washington, DC, 1997.

[6] S. Kumar and S. P. S. Kushwaha, "Modelling Soil Erosion Risk Based on RUSLE-3D Using GIS In A Shivalik Sub-Watershed," Journal of Earth System Science, vol. 122, no. 2, pp. 389-398, 2013.

[7] C. G. Karydas, T. Sekuloska and G. N. Silleos, "Quantification and Site-Specification of the Support Practice Factor When Mapping Soil Erosion Risk Associated with Olive Plantations in the Mediterranean Island of Crete," Environmental Monitoring and Assessment, vol. 149, pp. 1928, 2009.

[8] B. Pradhan, A. Chaudhari, J. Adinarayana and M. F. Buchroithner, "Soil erosion assessment and its correlation with landslide events using remote sensing data and GIS: A case study at Penang Island, Malaysia," Environmental Monitoring and Assessment, vol. 184, pp. 715-727, 2012.

[9] H. Asadi, M. Honarmand, M. Vazifedoust and A. Mousavi, "Assessment of Changes in Soil Erosion Risk Using RUSLE in Navrood Watershed, Iran," Journal of Agricultural Science and Technology, vol. 19, pp. 231-244, 2017.

[10] A. Kumar, M. Devi and B. Deshmukh, "Integrated Remote Sensing and Geographic Information System Based RUSLE Modelling for Estimation of Soil Loss in Western Himalaya, India," Water Resources Management, vol. 28, no. 10, pp. 3307-3317, 2014.

[11] D. Machiwal, P. Katara and H. K. Mittal, "Estimation of Soil Erosion and Identification of Critical Areas for Soil Conservation Measures using RS and GIS-based Universal Soil Loss Equation," Agricultural Research, vol. 4, no. 2, pp. 183-195, 2015.

[12] S. D. Vikhe and K. A. Patil, "Assessment of soil erosion in Sukhana basin using USLE, GIS and Remote Sensing: A case study," International Journal of Civil, Structural, Environmental and Infrastructure Engineering Research and Development, vol. 6, no. 4, pp. 71-78, 2016.

[13] M. Kouli, P. Soupios and F. Vallianatos, "Soil Erosion Prediction Using the Revised Universal Soil Loss Equation (RUSLE) In a GIS Framework, Chania, Northwestern Crete, Greece," Environmental Geology, vol. 57, no. 3, pp. 483-497, 2009.

[14] P. Panagos, P. Borrelli, K. Meusburger, E. H. van der Zanden, J. Poesen and C. Alewell, "Modelling the effect of support practices (P-factor) on the reduction of soil erosion by water at European scale," Environmental Science \& Policy, vol. 51, pp. 23-34, 2015. 
A. Bhadra et al. 